\title{
NEUTROPHIL GELATINASE-ASSOCIATED LIPOCALIN AS AN EARLY BIOMARKER OF ACUTE KIDNEY INJURY IN NEWBORNS
}

\author{
Silvana Naunova-Timovska ${ }^{1}$, Svetlana Cekovska ${ }^{2}$, Emilija Sahpazova $^{1}$ and Velibor Tasić ${ }^{1}$ \\ ${ }^{1}$ University Children's Hospital, Faculty of Medicine, \\ Ss. Cyril and Methodius University in Skopje, Skopje, Republic of North Macedonia; \\ ${ }^{2}$ Institute of Medical and Experimental Biochemistry, Faculty of Medicine, \\ Ss. Cyril and Methodius University in Skopje, Skopje, Republic of North Macedonia
}

\begin{abstract}
SUMMARY - The aim of the study was to determine the incidence, risk factors and efficiency of the neutrophil gelatinase-associated lipocalin (NGAL) biomarker in early diagnosis of acute kidney injury (AKI) in newborns. The study was designed as a prospective, clinical, epidemiological investigation conducted in the period of three years, which included 50 newborns with AKI hospitalized in the Neonatal Intensive Care Unit, University Children's Hospital in Skopje. The estimated prevalence of AKI was $6.4 \%$, while the prevalence according to RIFLE classification was $8.7 \%$. Perinatal asphyxia was a common predisposing factor associated to kidney injury. The mortality rate was $32 \%$ and was significantly higher in the group of newborns with congenital heart diseases. There was a significant difference between NGAL values and creatinine values on the day of admission. There was a significant difference in NGAL values between newborns with AKI and lethal outcome and newborns without lethal outcome ( $\mathrm{p}<0.001)$. In conclusion, AKI is a life-threatening condition. It is an independent contributor to mortality. Urinary NGAL is an early predictive biomarker of AKI in critically ill newborns.
\end{abstract}

Key words: Risk factors; Early diagnosis; Acute kidney injury; Infant, newborn; Biomarkers; Lipocalin-2

\section{Introduction}

Acute kidney injury (AKI) is a common clinical problem in newborns in the Neonatal Intensive Care Unit (NICU). It is a sudden, often reversible decrease in kidney function that results in deterioration of kidney ability to excrete urine in sufficient quantity and adequate composition, rendering it unable to maintain normal homeostasis of body fluids and electrolytes ${ }^{1-5}$.

Because of immaturity, neonatal kidney is particularly sensitive to reduction of kidney function. Neonatal glomerular filtration rate (GFR) is $25 \%$ compared

Correspondence to: Silvana Naunova-Timovska, $M D, P h D$, University Children's Hospital, 17 Vodnjanska, 1000 Skopje, Macedonia

E-mail: silvanatimovska@yahoo.com

Received June 18, 2018, accepted July 18, 2018 to adults, so any reduction in kidney function leads to kidney damage. The incidence of AKI in the neonatal population is $8 \%$ to $24 \%$, and the mortality rate ranges up to $35 \%{ }^{6-9}$.

The predisposing factors associated with neonatal kidney injury are certain clinical conditions such as perinatal asphyxia, neonatal sepsis, prematurity, meconium aspiration syndrome, congenital heart diseases, therapeutic interventions and other nephrotoxic drugs. Appropriate treatment of associated comorbidities and reduction in the use of potential nephrotoxic drugs reduce the risk of AKI in neonates in NICU ${ }^{10-14}$.

Because of the need of timely and appropriate diagnostics and assessment of the severity of kidney injury, RIFLE classification is used in neonates with AKI. Liborio et al. ${ }^{15}$ made adaptation to the neonatal RIFLE classification, in which the corrected values of 
serum creatinine and 24-hour urine output are taken as criteria. This classification includes three levels that classify the severity of disease (risk, damage and insufficiency) and two levels which classify the outcome of kidney injury ${ }^{17-21}$.

So far, the diagnosis of kidney injury has been based on the determination of serum creatinine, which is the most commonly used parameter for GFR. However, its use in the neonatal period is significantly limited. Namely, during the first 2 to 3 days of life, serum creatinine reflects the function of the maternal kidneys, showing higher values that subsequently decrease in the following days. On the other hand, the level of serum creatinine may change and increase, even after 48-72 hours of the initial kidney injury. Therefore, serum creatinine is considered as a late functional marker of kidney injury ${ }^{22}$.

Renal biomarkers can detect kidney injury in the first 2 to 3 hours of its occurrence, even before there is a decrease in diuresis and an increase in serum creatinine. Several renal biomarkers are described in the literature such as cystatin C, interleukin 18 (IL-18) and neutrophil gelatinase-associated lipocalin (NGAL) ${ }^{23,24}$.

In our study, we used NGAL, a small (25 kDa) glycoprotein from the family of lipoclins that is a compound of 178 amino acids and is found in specific granules in neutrophils. It is a protease-resistant polypeptide that is freely filtered through the glomeruli, is reabsorbed into the proximal tubule and eventually secreted by the urine. Its values largely reflect damage to endothelial cells of the tubules, but not reduction of glomerular filtration. The serum and urinary NGAL concentrations correlate with the severity of the disease, indicating the degree of current kidney injury. Therefore, NGAL represents the most promising biomarker for early detection of AKI. Its use allows us to make the right clinical decisions at the right time, before the illness is clinically manifest, and take appropriate measures to prevent renal function decline ${ }^{25}$.

The aim of the study was to determine the incidence, risk factors and efficiency of the NGAL biomarker in early diagnosis of neonatal AKI.

\section{Patients and Methods}

The study was designed as a prospective, clinical, epidemiological investigation conducted in the period of three years, which included 50 newborns with AKI hospitalized in NICU, University Children's Hospital in Skopje.

The criteria for inclusion in the study were infants up to 28 days of postnatal age; infants treated in NICU due to certain pathological condition, development of kidney injury, AKI defined by elevated serum creatinine $(>130 \mathrm{mmol} / \mathrm{L}$ in infants younger than 33 weeks and $>90 \mathrm{mmol} / \mathrm{L}$ in infants older than 33 weeks), and presence of oliguria (less than $1.0 \mathrm{~mL} / \mathrm{kg} / \mathrm{h}$ ). According to our criteria, all infants older than 28 days of age with less than 24 hours of hospitalization and infants having undergone cardiac surgery interventions were excluded from the study.

Data from medical records of the admitted neonates with AKI were analyzed. The neonates were analyzed according to gender, birth weight, gestational age and comorbid conditions such as sepsis, asphyxia, prematurity, meconium aspiration syndrome, and congenital heart diseases that were associated with AKI. All the newborns included in the study were classified according to the neonatal RIFLE classification criteria. Laboratory examinations of serum creatinine values were performed by use of a Kodak camera dry biochemistry at the Laboratory of Biochemistry, University Children's Hospital.

In this study, the NGAL biomarker was applied for the first time at our institution. It was analyzed in urine samples collected with urinary sachet or urinary catheter. In the investigated group of patients (infants with documented acute renal impairment), urine was collected on two occasions (day 0 as day of receipt and day 3 of receipt). Urine samples were frozen at -70 to $-80{ }^{\circ} \mathrm{C}$ and were transferred to the Department of Biochemistry

The concentration of NGAL in urine specimens was determined in duplicate, in the Department of biochemistry, by using NGAL ELISA method (Bioporto, Hellerup, Denmark). The assay is a sandwich ELISA performed in microwells coated with a nomoclonal antibody to human NGAL.

The material was statistically analyzed using the methods of descriptive statistics. To determine the significance of differences in the parameters, the tests for independent samples were used. The level of statistical significance was set at $\mathrm{p}<0.05$.

This study was conducted during preparation of the $\mathrm{PhD}$ thesis (S.N.T) and was approved by the Ethics Committee of the Skopje Medical School. Informed consent was obtained from the newborn parents. 


\section{Results}

Of the total of 770 patients hospitalized at the NICU, University Children's Hospital in the period of three years (2014-2016), 50 infants with documented AKI were evaluated in the study. According to gender distribution, male infants predominated $(n=34 / 50$; $68 \%)$ over female ones $(n=16 / 50 ; 32 \%)$. The male to female ratio was 2.1:1. Most of the neonates involved in the study were born at term $(n=31 ; 62 \%)$, whereas

Table 1. Demographic characteristics of hospitalized neonates with acute kidney injury

\begin{tabular}{|l|l|}
\hline Characteristic & \\
\hline Subjects, $\mathrm{N}$ & 50 \\
\hline Age (days): & $4.49 \pm 5.7$ \\
Mean \pm SD & $2-28$ \\
Range & \\
\hline Sex: & $34(68)$ \\
$\quad$ Male, $n(\%)$ & $16(32)$ \\
Female, $n(\%)$ & \\
\hline Gestational age (wk): & $37.34 \pm 3.01$ \\
Mean \pm SD & $26-40$ \\
Range & \\
\hline Weight (g): & $2890.80 \pm 898.12$ \\
Mean \pm SD & $780-4850$ \\
Range & $12.82 \pm 8.42$ \\
\hline Duration of stay (days): & $5-28$ \\
Mean \pm SD & \\
Range & \\
\hline
\end{tabular}

Table 2. Predisposing factors for acute kidney injury in newborns

\begin{tabular}{|l|l|l|}
\hline Predisposing factor & $\begin{array}{l}\text { Number of } \\
\text { patients (n) }\end{array}$ & Percent \\
\hline Asphyxia & 15 & 30 \\
\hline $\begin{array}{l}\text { Meconium aspiration } \\
\text { syndrome }\end{array}$ & 5 & 10 \\
\hline Congenital heart disease & 6 & 12 \\
\hline $\begin{array}{l}\text { Prematurity with respiratory } \\
\text { distress syndrome }\end{array}$ & 12 & 24 \\
\hline Sepsis & 12 & 24 \\
\hline
\end{tabular}

19 (38\%) were born prematurely. Demographic characteristics of the study newborns are shown in Table 1.

Table 2 shows the prevalence and distribution of predisposing factors associated with AKI among the neonates. Perinatal asphyxia was the most common predisposing factor observed in 15 (30\%) newborns, with male predominance (Fig. 1). Other predisposing factors were neonatal sepsis and prematurity with respiratory distress syndrome observed in 12 (24\%) neonates, congenital heart diseases in six $(12 \%)$ and meconium aspiration syndrome in five $(10 \%)$ neonates.

The mortality among hospitalized newborns with AKI was $32 \%$. It was significantly higher in the group of patients with congenital heart diseases than in the others ( $\mathrm{p}=0.01)$. Distribution of mortality according to predisposing factors associated with AKI is illustrated in Figure 2.

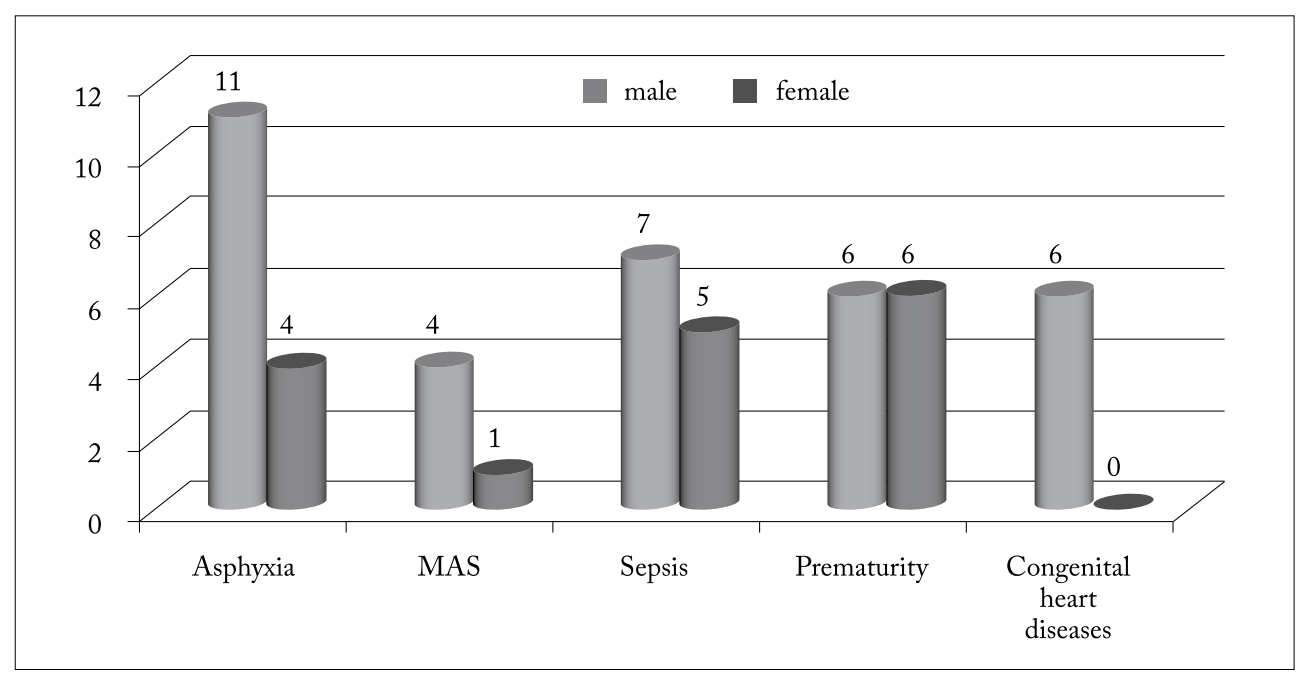

Fig. 1. Predisposing factors for acute kidney injury according to gender.

MAS = meconium aspiration syndrome 


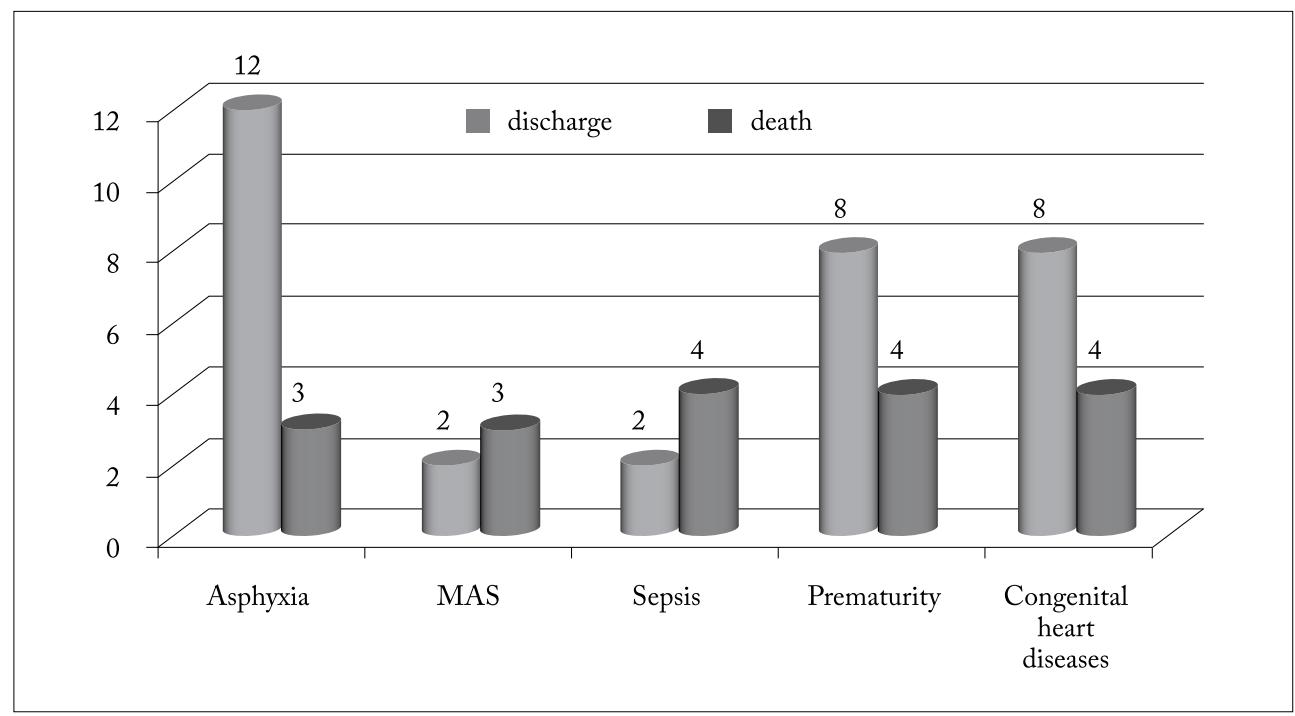

Fig. 2. Distribution of mortality according to predisposing factors associated with acute kidney injury.

MAS = meconium aspiration syndrome

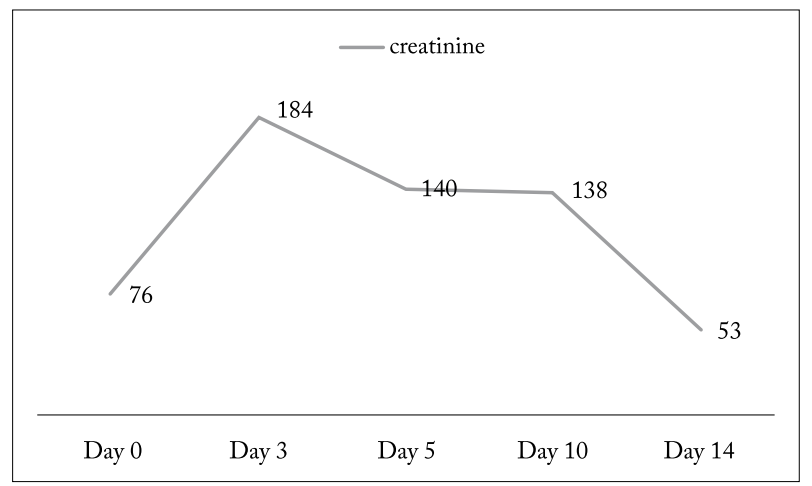

Fig. 3. Distribution of serum creatinine in newborns with acute kidney injury.

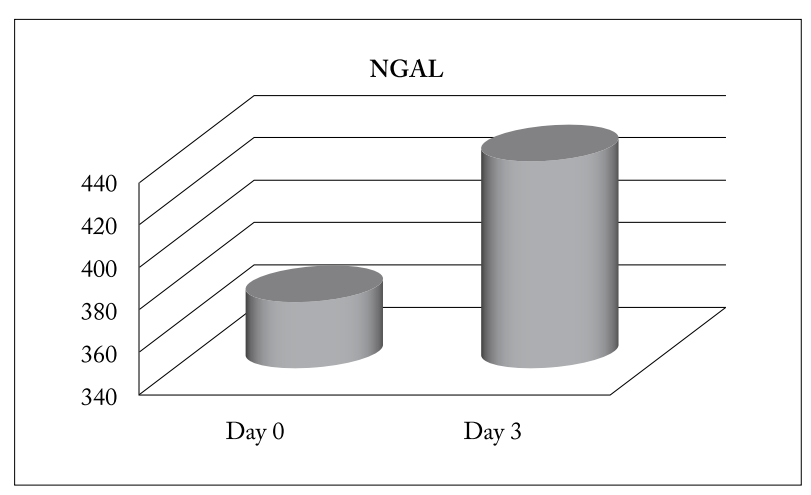

Fig. 4. Neutrophil gelatinase-associated lipocalin (NGAL) monitoring on the day of hospitalization and three days later.
Table 3. Distribution of serum creatinine and urinary NGAL in newborns with acute kidney injury

\begin{tabular}{|c|c|c|c|}
\hline Parameter & Mean \pm SD & Min-max & Median \\
\hline \multicolumn{4}{|l|}{$\begin{array}{l}\text { Creatinine } \\
(\mathrm{mmo} / \mathrm{L}):\end{array}$} \\
\hline $\begin{array}{l}\text { Day } 0 \\
\text { Day } 3\end{array}$ & \begin{tabular}{|l|}
$76.78 \pm 30.6$ \\
$184.44 \pm 103.74$
\end{tabular} & \begin{tabular}{|l|}
$34-180$ \\
$120-810$
\end{tabular} & \begin{tabular}{|l|}
75.5 \\
151.5
\end{tabular} \\
\hline \multicolumn{4}{|c|}{ NGAL (ng/mL): } \\
\hline $\begin{array}{l}\text { Day } 0 \\
\text { Day } 3\end{array}$ & \begin{tabular}{|l|}
$373.8 \pm 194.9$ \\
$439.4 \pm 254.7$
\end{tabular} & $\begin{array}{l}200-1100 \\
20-1350\end{array}$ & $\begin{array}{l}280.0 \\
310.0\end{array}$ \\
\hline
\end{tabular}

NGAL = neutrophil gelatinase-associated lipocalin

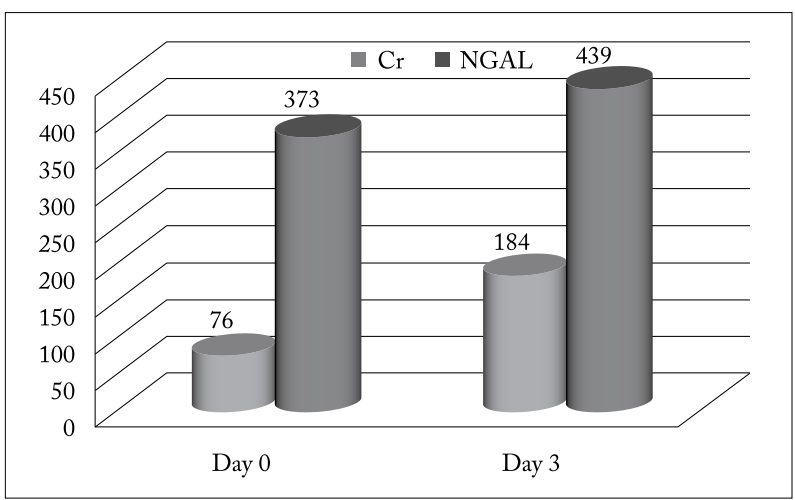

Fig. 5. Distribution of serum creatinine and urinary NGAL in newborns with acute kidney injury.

$\mathrm{Cr}=$ creatinine NGAL $=$ neutrophil gelatinase-associated lipocalin 
The mean serum creatinine level in newborns with AKI was $76.78 \pm 30.6 \mathrm{mmol} / \mathrm{L}$ on the day of admission to the NICU and $184.44 \pm 103.74 \mathrm{mmol} / \mathrm{L}$ after 72 hours. In the next days, serum creatinine showed a decreasing trend. Distribution of serum creatinine levels in newborns with AKI is shown in Figure 3.

Study results showed higher values of urinary NGAL in newborns with AKI on the day of admission $(373.8 \pm 194.9)$ and a slight upward trend, with further increase on the third day after admission (439.4 $\pm 254.7 ; p<0.001)$ (Fig. 4).

Distribution of creatinine and NGAL values among the neonates in shown in Table 3 and Figure 5. There was a significant difference between NGAL values and serum values on the day of admission to the NICU.

There was a significant difference in the values of urinary NGAL between newborns with AKI and lethal outcome and newborns without lethal outcome $(\mathrm{p}<0.001)$. The mean urinary NGAL values in neonates with AKI with lethal outcome was $586.39 \pm 182.3$ versus $254.22 \pm 28.5$ in neonates without lethal outcome (Fig. 6).

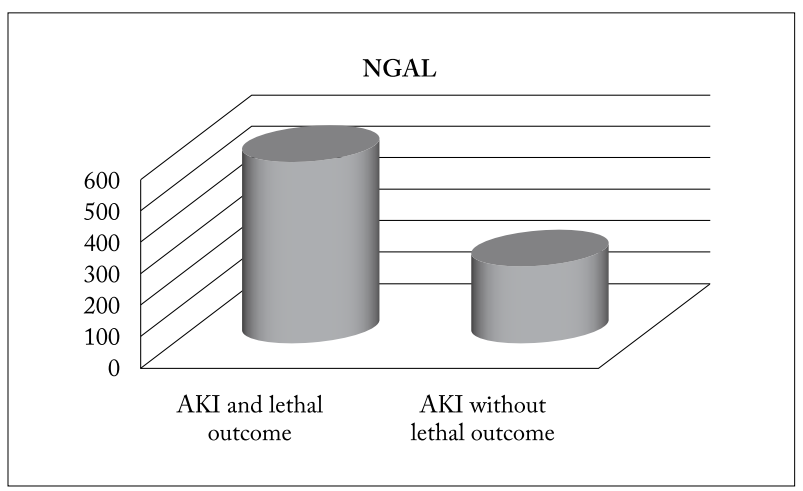

Fig. 6. Values of urinary NGAL in newborns with AKI and lethal outcome compared to newborns without lethal outcome.

$\mathrm{NGAL}=$ neutrophil gelatinase-associated lipocalin; AKI $=$ acute kidney injury

\section{Discussion}

The estimated prevalence of AKI in neonates according to the standard definition was $6.4 \%$, which is consistent with literature data. A similar finding has been reported from the study conducted by Vachvanichsanong et al. ${ }^{26}$, where the incidence of AKI in neonates was $6.3 \%$, whereas in the study by Bolat et $a l .{ }^{27}$ it was $8.0 \%$. However, there are opposite findings. Thus, Momtaz et al. ${ }^{28}$ report on the incidence of AKI of $1.5 \%$, Mortazavi et al. ${ }^{29}$ on $2.7 \%$, and Agras et al. ${ }^{30}$ on $3.4 \%$. We assume that these differences can be due to differences in the criteria for diagnosing kidney injury in newborns ${ }^{31}$. In our study, the prevalence of neonatal AKI according to RIFLE classification was 8.7\%, indicating that in the present study, the diagnosis of AKI must have been missed in the majority of neonates according to the standard classification. It is assumed that the therapy administered for other indications probably led to the resolution of kidney injury. This finding indicates that RIFLE classification can be used as a more sensitive method than the standard classification in the diagnosis and monitoring of kidney injury in neonates at $\mathrm{NICU}^{32}$.

The most common associated predisposing factor was perinatal asphyxia observed in 30\% of newborns, with a predominance of term male newborns born with a low Apgar score in the fifth minute of life. This finding correlates with the data reported from the study by Abu-Haweleh ${ }^{33}$, according to which $42 \%$ of AKI patients had perinatal asphyxia as a dominant contributing condition.

In our study, mortality rate was $32 \%$, which is consistent with the data reported by Kapoor et al. ${ }^{34}$. It was significantly higher in newborns with congenital heart disease and secondary development of sepsis, where invasive therapeutic procedures such as intubation and assisted ventilation were applied ${ }^{35}$.

In this study, NGAL was first applied as an early biomarker of AKI in newborns. Before the use of biomarker, the diagnosis of kidney injury was based on determination of serum creatinine. In our study, we found an increase in serum creatinine 72 hours after hospitalization of newborns at the NICU. This finding shows that by measuring serum creatinine, the disease can be detected when clear clinical signs and symptoms are already present. This confirms that serum creatinine is a late functional marker of kidney injury.

In our study, we detected significantly higher values of urinary NGAL on the day of admission of critically ill newborns at the NICU compared to creatinine values. This finding indicates that NGAL is a sensitive marker in the diagnosis of kidney injury. These data correlate with the data reported by Nickolas et al. ${ }^{36}$ and 
Youssef $e t a l .^{37}$, emphasizing the role of NGAL as a sensitive marker in detecting kidney injury.

Follow-up of urinary NGAL on the day of hospitalization of newborns at the NICU and three days later showed a growing trend of the average value. The finding of significantly higher NGAL values on initial measurement suggested that renal damage had probably occurred before hospitalization of newborns at the NICU. Namely, all critically ill newborns from the territory of the Republic of Macedonia are referred to our department, which is the only specialized tertiary center for intensive therapy. This explains the presence of kidney injury when admitting critically ill newborns in whom AKI has not yet been clinically manifested. On the other hand, the high values of urinary NGAL recorded on admission to the NICU confirm the role of NGAL as an early marker of kidney injury. Mishra et al..$^{38}$ and Devarajan ${ }^{39}$ in their studies also point to the ability of NGAL to early detect the newborns at risk of AKI.

The values of NGAL in newborns with AKI and lethal outcomes were significantly higher than in newborns without lethal outcome. This finding suggests that the level of urinary NGAL significantly correlates with the severity and outcome of the disease, indicating the extent of current kidney injury. Zappitelli et al. ${ }^{40}$ report similar results of significantly higher NGAL values in critically ill children with AKI and lethal outcomes.

The findings in our study confirm the applicability of the NGAL biomarker in the early diagnosis of AKI in newborns.

\section{Conclusion}

Acute kidney injury is a serious life-threatening condition, especially in the neonatal period. It is an independent contributor to mortality. In this study, NGAL as an early biomarker of AKI was used for the first time in our environment. NGAL provides an early diagnosis of kidney injury in the first hours of its occurrence, when the disease is not yet clinically manifested. That is why we propose its wider application as an early marker for the diagnosis of AKI in sick infants with different clinical conditions hospitalized at the NICU.

\section{References}

1. Schrier W, Wang W, Poole B, et al. Acute renal failure: definitions, diagnosis, pathogenesis, and therapy. J Clin Invest. 2004;114:5-14. DOI: 10.1172/JCI22353

2. Mak RH. Acute kidney injury in children: the dawn of a new era. Pediatr Nephrol. 2008;23:2147-9. DOI: 10.1007/s00467008-1014-8

3. Andreoli SP. Acute kidney injury in children. Pediatr Nephrol. 2009;24:253-63. DOI: 10.1007/s00467-008-1074-9

4. Vieux R, Hascoet JM, Merdariu D, et al. Glomerular filtration rate reference values in very preterm infants. Pediatrics. 2010; 125:1186.

5. Askenazi D. Evaluation and management of critically ill children with acute kidney injury. Curr Opin Pediatr. 2011;23 (2):201-7.

6. Subramanian S, Agarwal R, Deorari AK, et al. Acute renal failure in neonates. Indian J Pediatr. 2008;75(4):385-91. DOI: 10.1081/jdi-200026749

7. Moghal NE, Brocklebank JT, Maedow SR, et al. A review of acute renal failure in children: incidence, etiology and outcome. Clin Nephrol. 1998;49:91-5.

8. Ottonello G, Dessi A, Neroni P, et al. Acute kidney injury in neonatal age. J Pediatr Neonatal Med. 2014;3(2):030246.

9. Cataldi L, Leone R, Moretti U, et al. Potential risk factors for the development of acute renal failure in preterm newborn infants: a case-control study. Arch Dis Child Fetal Neonatal Ed. 2005;90(6):F514-9.

10. Doronjski A, Stojanovic V, Spasojevic S, et al. Acute renal failure in premature neonates. Vojnosanit Pregl. 2009;66(11): 863-7. DOI: $10.2298 / v s p 0911863 d$

11. Gupta BD, Sharma P, Bagla J, et al. Renal failure in asphyxiated neonates. Indian Pediatr. 2005;42(9):928-34.

12. Vishwanathan S, Manyam B, Azhibekou T, et al. Risk factors associated with acute kidney injury in extremely low birth weight (ELBW) infants. Pediatr Nephrol. 2012;27(2):303-11.

13. Gopal Girish. Acute kidney injury in perinatal asphyxia. Indian J Pharm Biol Res. 2014;2(2):60-5

14. Bailey D, Phan V, Litalien C, et al. Risk factors of acute renal failure in critically ill children: a prospective descriptive epidemiological study. Pediatr Crit Care Med. 2007;8:29-35. DOI: 10.1097/01.pcc.0000256612.40265.67

15. Liborio AB, Castello BK, Torres de Melo BC. Acute kidney injury in neonates: from urine output to new biomarkers. Biomed Res Int. 2014;2014:601568.

16. Uchino S, Bellomo R, Goldsmith D, et al. An assessment of the RIFLE criteria for acute renal failure in hospitalized patients. Crit Care Med. 2006;34:1913-7. DOI: 10.1097/01.CCM.00 $00224227.70642 .4 \mathrm{~F}$

17. Akcan-Arikan A, Zappitelli M, Loftis LL, et al. Modified RIFLE criteria in critically ill children with acute kidney injury. Kidney Int. 2007;71:1028-35. 
18. Plotz FB, Bouma AB, van Wijk JA, et al. Pediatric acute kidney injury in the ICU: an independent evaluation of pRIFLE criteria. Intensive Care Med. 2008;34:1713-7.

19. Bresolin N, Bianchini AP, Haas CA. Pediatric acute kidney injury assessed by pRIFLE as a prognostic factor in the intensive care unit. Pediatr Nephrol. 2013;28(3):485-92. DOI: 10.1007/ s00467-012-2357-8

20. Mohkam M, Kompani F, Afjeii A, et al. RIFLE criteria in critically ill neonates with acute kidney injury. J Pediatr Nephrol. 2015;3(1):16-21.

21. Bateman DA, Thomas W, Parravicini E, et al. Serum creatinine concentration in very-low-birth-weight infants from birth to 34-36 wk postmenstrual age. Pediatr Res. 2015;77:696. DOI: 10.1038/pr.2015.25

22. Devarajan P. Emerging biomarkers of acute kidney injury. Contrib Nephrol. 2007;156:203-12.

23. Herget-Rosenthal S, Pietruck F, Volbracht L, et al. Serum cystatin $\mathrm{C}-$ a superior marker of rapidly reduced glomerular filtration after uninephrectomy in kidney donors compared to creatinine. Clin Nephrol. 2005;64:41-6. DOI: 10.5414/cnp 64041

24. Bennett M, Dent CL, Ma Q et al. Urine NGAL predicts severity of acute kidney injury after cardiac surgery: a prospective study. Clin J Am Soc Nephrol. 2008;3:665-9. DOI: 10.2215/ CJN.04010907

25. Devarajan P. Neutrophil gelatinase-associated lipocalin (NGAL): a new marker of kidney disease. Scand J Clin Lab Invest Suppl. 2008;241:89-94. DOI: 10.1080/00365510802 150158

26. Vachvanichsanong P, Dissaneewate P, Lim A, et al. Childhood acute renal failure: 22-year experience in a university hospital in southern Thailand. Pediatrics. 2006;118(3):786-91.

27. Bolat F, Comert S, Bolat G, et al. Acute kidney injury in a single neonatal intensive care unit in Turkey. World J Pediatr. 2013;9(4):323-9. DOI: 10.1007/s12519-012-0371-3

28. Momtaz HE, Sabzehei MK, Rasuli M, et al. The main etiologies of acute kidney injury in the newborns hospitalized in the neonatal intensive care unit. J Clin Neonatol. 2014;3(2):99-102.

29. Mortazavi F, Hosseinpour S, Nejati N. Acute kidney failure in neonatal period. Iran J Kidney Dis. 2009;3(3):136-40. DOI: 10.4103/2249-4847.134691
30. Agras P, Tarcan A, Baskin E, et al. Acute renal failure in neonatal period. Ren Fail. 2004;26(3):305-9.

31. Chertow GM, Burdick E, Honour M, et al. Acute kidney injury, mortality, length of stay, and costs in hospitalized patients. J Am Soc Nephrol. 2005;16:3365-70. DOI: 10.1681/ ASN.2004090740

32. Weintraub AS, Carey A, Connors J, et al. Relationship of maternal creatinine to first neonatal creatinine in infants $<30$ weeks gestation. J Perinatol. 2015;35:401.

33. Abu-Haweleh AF. Acute renal failure in newborn: etiology and mortality rate in Jordan patients. Saudi J Kidney Dis Transpl. 1998;9:18-21.

34. Kapoor K, Jajoo M, Dabas V, et al. Predictors of mortality in neonates with acute renal failure. Iran J Pediatr. 2013;23(3): 321-6.

35. Mishra J, Ma Q, Prada A, et al. Identification of neutrophil gelatinase-associated lipocalin as a novel early urinary biomarker for ischemic renal injury. J Am Soc Nephrol. 2003; 14:2534-43.

36. Nickolas TL, O’Rourke MJ, Yang J, et al. Sensitivity and specificity of a single emergency department measurement of urinary neutrophil gelatinase associated lipocalin for diagnosing acute kidney injury. Ann Intern Med. 2008;148:810-9. DOI: 10.7326/0003-4819-148-11-200806030-00003

37. Youssef D, Abd-Elrahman H, Shehab N, et al. Incidence of acute kidney injury in the neonatal intensive care unit. Saudi J Kidney Dis Transpl. 2015;26(1):67-72. DOI: 10.4103/13192442.148738

38. Mishra J, Dent C, Tarabishi R, et al. Neutrophil gelatinase associated lipocalin (NGAL) as a biomarker for acute renal injury after cardiac surgery. Lancet. 2005;365:1231-8. DOI: 10.1016/S0140-6736(05)74811-X

39. Devarajan P. Neutrophil gelatinase-associated lipocalin: a promising biomarker for human acute kidney injury. Biomark Med. 2010;4(2):265-80. DOI: 10.2217/bmm.10.12

40. Zappitelli M, Washburn KK, Arikan AA, et al. Urine neutrophil gelatinase-associated lipocalin is an early marker of acute kidney injury in critically ill children: a prospective cohort study. Crit Care. 2007;11:84. 


\section{Sažetak}

\section{LIPOKALIN UDRUŽEN S NEUTROFILNOM GELATINAZOM KAO RANI BIOLOŠKI BILJEG AKUTNOG OŠTEĆENJA BUBREGA U NOVOROĐENČADI}

\section{S. Naunova-Timovska, S. Cekovska, E. Sahpazova i V. Tasić}

Cilj istraživanja bio je utvrditi incidenciju, čimbenike rizika i učinkovitost biološkog biljega lipokalina udruženog s neutrofilnom gelatinazom (neutrophil gelatinase-associated lipocalin, NGAL) u ranoj dijagnostici akutnog oštećenja bubrega $(\mathrm{AOB})$ kod novorođenčadi. Istraživanje je provedeno kao prospektivna klinička epidemiološka studija kroz razdoblje od tri godine, a obuhvatila je 50 novorođenčadi s AOB hospitalizirane u Neonatalnoj jedinici intenzivnog liječenja (NJIL) Sveučilišne dječje bolnice u Skopju. Procijenjena učestalost AOB bila je 6,4\%, dok je učestalost prema klasifikaciji RIFLE iznosila 8,7\%. Perinatalna asfiksija bila je čest predisponirajući čimbenik udružen s oštećenjem bubrega. Stopa smrtnosti bila je 32\% i bila je značajno viša u skupini novorođenčadi s kongenitalnim srčanim bolestima. Utvrđena je značajna razlika među vrijednostima NGAL i kreatinina na dan prijma u NJIL. Značajna razlika zabilježena je u vrijednostima NGAL između novorođenčadi s AOB i smrtnim ishodom i novorođenčadi bez smrtnog ishoda $(\mathrm{p}<0,001)$. U zaključku, AOB je za život opasno stanje koje neovisno doprinosi smrtnosti. NGAL u mokraći je rani predskazujući biološki biljeg za AOB kod kritično bolesne novorođenčadi.

Ključne riječi: Rizični čmbenici; Rana dijagnostika; Akutno oštećenje bubrega; Novorođenče; Biomarkeri; Lipokalin-2 